\title{
Analisis Pemanfaatan Dana Desa Dalam Meningkatkan Ekonomi Masyarakat
}

\section{Analysis of Village Fund Utilization in Improving Community Economy}

\section{Rinto Alexandro ${ }^{\text {* }}$ \\ Fendy Hariatama ${ }^{2}$ \\ Seno Saputra ${ }^{3}$}

*123Pendidikan Ekonomi FKIP Universitas Palangka Raya, Palangka Raya, Kalimantan Tengah, Indonesia

*email:

rinto.alexandro@fkip.upr.ac.id

\section{Kata Kunci:}

Dana Desa

Ekonomi Masyarakat Desa

Keywords:

Village Fund

Village Community Economy

\begin{abstract}
Abstrak
Dana desa yang dikelola dengan transfaran dan penuh rasa tanggungjawab memiliki peran yang positif sebagai salah satu penggerak roda ekonomi pembangunan desa. Penelitian ini bertujuan untuk menganalisis pemanfaatan dana desa dalam meningkatkan ekonomi masyarakat pada Desa Tumbang Empas Kecematan Mihing Raya Kebupaten Gunung Mas Provinsi Kalimantan Tengah. Faktor penting lainnya adalah sebagai dorongan yang mampu mengubah dan memperlancar roda pembangunan ekonomi pinggiran di desa dengan penggunaan dana desa yang berorientasi pada masyarakat. Penelitian menggunakan metode kulitatif. Sumber data adalah hasil wawancara dengan Kepala Desa, Sekretaris Desa, Tokoh Masyrakat dan Masyrakat Desa Tumbang Empas. Teknik pengumpulan data yang digunakan dalam penelitian ini adalah observasi, wawancara, dan dokumentasi. Teknik analisis data mengunakan reduksi, penyajian, dan penariakan kesimpulan. Hasil penelitian menunjukan dana desa dimanfaatkan sebagai sarana pembagunan ekonomi desa untuk meningkatkan ekonomi masyarakat. Dana desa memiliki peran yang positif sebagai penggerak kemajuan ekonomi pembangunan desa. Dapat disimpulkan pengelolaan dana desa telah memberikan manfaat untuk masyarakat dalam meningkatkan perekonomian.
\end{abstract}

(C) 2021 The Authors. Published by Institute for Research and Community Services Universitas Muhammadiyah Palangkaraya. This is Open Access article under the CC-BY-SA License (http://creativecommons.org/licenses/by-sa/4.0/).

\section{PENDAHULUAN}

Dalam Undang-Undang Nomor 33 Tahun 2004 tentang perimbangan keuangan pusat daerah, dimana hal ini disambut positif dari semua pihak dengan segenap harapan bahwa melalui otonomi daerah akan dapat merangsang terhadap adanya upaya untuk menghilangkan praktek-praktek sentralistik yang pada satu sisi dianggap kurang menguntungkan bagi daerah dan penduduk lokal. Prinsip otonomi daerah menggunakan prinsip otonomi seluas luasnya dalam arti daerah diberikan kewenangan mengurus dan mengatur semua urusan pemerintahan di luar yang ditetapkan dalam Undang-Undang.

Peran pemerintah dalam membangun desa sangat penting dimana pemerintah adalah unit pelaksana utama dalam pembangunan yang akan dibantu oleh beberapa lembaga yang lain seperti Badan Pengelolaan Keuangan Desa, Permusyawaratan Desa (BPD) dan Lembaga Pemberdayaan Masyarakat (LPM) serta Masyarakat 
Desa. Berkenaan dengan desentralisasi/otonomi maksud pemberian Dana Desa (DD) adalah sebagai bantuan stimulan atau dana perangsang untuk mendorong dalam membiayai program Pemerintah Desa yang ditunjang dengan partisipasi swadaya gotong royong masyarakat dalam melaksanakan kegiatan pemerintahan dan pemberdayaan masyarakat. Melihat pada apa yang diamanatkan melalui dana desa ini, program pembangunan dan pemberdayaanlah yang memang menjadi tujuan utamanya, dan peran pemerintah desa dalam hal ini menjadi kunci bagaimana memanfaatkan dana tersebut dengan semestinya, yakni untuk pembangunan dan pemberdayaan. Maka dari itu, pemerintah desa harus kembali pada tugas pokok dan fungsinya sebagai pemimpin desa, yakni diantaranya:

I. Membina kehidupan masyarakat desa.

2. Membina ekonomi desa.

3. Mengordinasikan pembangunan desa secara partisipatif.

4. Melaksanakan wewenang lain sesuai dengan peraturan perundang undangan.

Berdasarkan hasil wawancara dengan beberapa masyarakat, mereka menuturkan bahwa pemerintah desa telah melakukan program pembangunan infrastruktur didaerahnya. Pelaksanaan program pembangunan tersebut merupakan hasil dari musyawarah antar dusun, yang kemudian diajukan kepada pemerintah desa sebagai rencana pembangunan pedesaan. Pembangunan tersebut merupakan murni swasembada dari pemerintah desa, dan dengan adanya kegiatan pembangunan infrastruktur ini mereka menuturkan bahwa masyarakat tersebut merasa senang dan merasa terbantu dengan adanya kegiatan pembangunan. Akan tetapi Pada tahun 2014 sebulum pemerintah desa tumbang empas menerima aliran Dana Desa (DD) secara keseluruhan program pemerintahan desa belum dapat berjalan dengan baik karena keterbatasan dana yang dimiliki, sehingga program yang dilaksanakan oleh pemerintah desa belum dapat memberikan hasil yang maksilmal kepada masyarakat dalam hal pemberdayaan yang tepat guna. Dari data sementara yang penulis peroleh dari Laporan Anggaran Pendapatan dan Belanja Desa (APBDes) Desa tumbang empas, Dana Desa yang diterima Desa Tumbang Empas Periode tahap I tahun 2019 adalah

Tabel I. Dana Desa Yang Diterima Atau Pendapatan Transfer Tahun 2019

\begin{tabular}{c|c|c}
\hline NO & Tahun & Jumlah \\
\hline I & 2019 & Rp. I.462.I56.500,00 \\
Jumlah & & Rp. I.462.I56.500,00 \\
\hline
\end{tabular}

Sumber: APBD Desa tumbang empas 2019

Sehingga dengan adanya dana desa tersebut penulis merasa tertarik untuk melakukan sebuah penelitian dengan rumusan masalah bagaimana pemanfaatan dana desa yang dilakukan oleh pemerintah desa Tumbang Empas, serta menganalisis pemanfaatan dana desa tersebut dalam kaitannya dengan peningkatan ekonomi masyarakat yang berada di desa tersebut.

Tujuan yang ingin dicapai adalah pemanfaatan dana desa akan dapat memberikan dampak yang positif dalam meningkatkan perekonomian masyarakat yang berada di desa Tumbang Empas.

Dalam penelitian yang lain, Putro dan Kartini (2020) menyampaikan penggunaan dana desa harus sesuai dengan peraturan menteri desa no 16 tahun 2018 tentang prioritas penggunaan dana desa, sehingga dengan pemanfaatan dana desa yang baik dan sesuai diharapkan dapat memberikan peningkatan ekonomi bagi masyarakat sekitar.

Selain itu dalam pelaksanaannya pemerintah desa juga disarankan untuk membuat laporan keuangan atas penggunaan dana desa tersebut seperti apa yang disampaikan Ayustia (2019). Dengan demikian transfaransi pengunaan dana desa dapat menjadi peningkatan kepercayaan masyarakat kepada pemerintah desa.

Dari latar belakang di atas penulis akhirnya mengangkat sebuah judul "Analisis Pemanfaatan Dana Desa Dalam Meningkatkan Ekonomi Masyarakat" untuk dapat dikaji lebih lanjut. 


\section{METODOLOGI}

Berdasarkan tujuan penelitian, metode yang digunakan adalah metode penelitian deskriptif dengan pendekatan kuantitatif. Menurut (Sugiyono, 2007), metode penelitian kualitatif merupakan suatu penelitian yang digunakan untuk meneliti pada objek yang alamiah dimana peneliti adalah sebagai instrumen kunci. Untuk memperoleh data yang akurat dalam penelitian ini, penulis menggunakan beberapa teknik pengumpulan data, yaitu observasi/pengamatan, wawancara, dan dokumentasi. Menurut (Widoyoko, 2014:46) observasi merupakan "pengamatan dan pencatatan secara sistematis terhadap unsur-unsur yang nampak dalam suatu gejala dalam objek penelitian". Dokumentasi dalam penelitian ini adalah mengumpulkan data yang peroleh dari desa tumbang empas. Menurut (Afifuddin, 2009:|3I) wawancara adalah metode pengambilan data dengan cara menanyakan sesuatu kepada seseorang yang menjadi informan atau responden.

Penelitian ini dilakukan Desa Tumbang Empas, Kecamatan Mihing Raya Kebupaten Gunung Mas Provinsi Kalimantan Tengah. Sumber data peneliti peroleh melalui pengamatan atau observasi langsung yang didukung dengan wawancara terhadap informan dan dokumentasi.

Tabel II. Daftar Tabel Informan

\begin{tabular}{c|l|l}
\hline No & \multicolumn{1}{|c}{ Nama } & \multicolumn{1}{c}{ Jabatan } \\
\hline I & Beninrianto, A.Md & Kepala Desa \\
2 & Popo, Se & Sekretaris Desa \\
3 & Berlinson & Mantir Adat \\
4 & Aster Santara & Masyarakat Desa \\
& & Tumbang Empas \\
5 & Alam Macan & Masyarakat Desa \\
& & Tumbang Empas \\
\hline
\end{tabular}

Sumber: Data Desa

\section{HASIL DAN PEMBAHASAN}

Sejarah Singkat Desa Tumbang Empas

Desa tumbang empas adalah desa yang dulunya adalah desa pindahan pada tahun 1990 yang dulunya dinamai dengan desa luwuk sungkai yang berada pada kecematan sepang kebupaten Kapuas, dan sekarang diganti nama dengan desa tumbang empas kecematan mihing raya kebupaten gunung mas.

Tabel III. Batas Wilayah Desa Tumbang Empas

\begin{tabular}{ll}
\hline Batas sebelah timur & Desa Murui Raya (Kapuas) \\
\hline Batas sebelah barat & Kecematan Rungan \\
Batas sebelah utara & Desa rangan tate \\
Batas sebelah selatan & Desa Tuyun \\
\hline
\end{tabular}

Sumber : Data Desa 2019

Tabel IV. Sarana Dan Prasarana

\begin{tabular}{c|lc}
\hline NO & \multicolumn{1}{|c}{ Sarana prasarana } & Jumlah \\
\hline I & Sekolah TK & I \\
2 & SDN I Tumbang Empas & I \\
3 & SMPN I Atap Mihing raya & $\mathrm{I}$ \\
4 & SMAN I Mihing raya & $\mathrm{I}$ \\
5 & Pustu & $\mathrm{I}$ \\
6 & Jembatan & 3 \\
7 & Gereja & 3 \\
8 & Kantor desa & $\mathrm{I}$ \\
9 & Balai basarah AHK & $\mathrm{I}$ \\
I0 & Lapangan poli & 2 \\
II & Posysndu & $\mathrm{I}$ \\
I2 & Jalan pemda & $\mathrm{I}$ \\
\hline
\end{tabular}

Sumber : Data Desa 2019

Tabel V. Jumlah Penduduk Desa Tumbang Empas 2019 Data Jumlah Penduduk Desa Tumbang Empas 2019

\begin{tabular}{llll}
\hline Rt I & Rt 2 & Rt 3 & Rt 4 \\
250 Orang & 193 Orang & 147 Orang & 230 Org
\end{tabular}

Sumber Data Tahun 2019

Tabel VI. Mata Pencaharian Masyarakat Desa Tumbang Empas

Data Mata Pencaharian Dan Sumber Ekonomi Masyarakat Desa Tumbang Empas

Pegawai Swasta Penambang/ Pedagang Tni/Polri Negeri Sipil Penyedot

12 Orang 30 org $75 \%$ dari 20 Orang 2 Orang

Sumber Data Tahun 2019

Pemanfaatan Dana Desa Oleh Pemerintah Desa

Tumbang Empas, Kecamatan Mihing Raya, Kabupaten Gunung Mas.

Faktor penting lainnya sebagai stimulus yang mampu mengubah dan memperlancar roda pembangunan ekonomi pinggiran di desa adalah keberadaan dan pemanfaatan Dana Desa. Kenapa demikian? Program Desa akan berjalan sesuai target waktu dan sesuai 
harapan apabila didukung oleh dana desa yang akan memperlancar proses pembangunan di desa. Dana Desa akan bermanfaat dan memiliki peran yang positif sebagai pelumas roda ekonomi pembangunan desa, apabila memenuhi klasifikasi antara lain penggunaannya dengan tata kelola yang baik, menghindari penyalahgunaan penggunaannya, transparan, optimal melalui swakelola, dan dapat dipertanggungjawabkan dengan melakukan pengawasan ketat.

\section{Tata Kelola Dana Desa}

Dengan tata kelola pemerintahan desa yang baik melalui prinsip-prinsip good governance maka upaya menuju desa sejahtera mandiri bukan hal yang tak mungkin. Maka pengungkapan kasus akhir-akhir ini, di beberapa media menjadi tolak ukur keberhasilan dalam penerapan prinsip good governance. Pemeriksaan terhadap beberapa personel pemerintah desa oleh aparat hukum karena pelaksanaan pembangunan yang gagal, tidak berkualitas, salah sasaran, dan tidak sesuai kebutuhan merupakan kemunduran yang harus dievaluasi. Menuju desa sejahtera mandiri yang maju dan sejahtera hanya akan dicapai dengan tata kelola pemerintah yang baik, optimal, transparan dan dapat dipertanggungjawabkan.

Hasil penelitian menunjukan program pemerintah desa dalam tata kelola dana desa sudah berjalan, terlihat dari pembangunan yang ada seperti jembatan, posyandu, gorong-gorong yang sangat dirasakan dampaknya oleh masyarakat desa tumbang empas.

Menghindari Penyalahgunaan Dana Desa

Akhir-akhir ini banyak pemberitaan di media cetak maupun media online soal Dana Desa yang diselewengkan. Komisi Pemberantasan Korupsi (KPK) bahkan sudah mengantongi 362 laporan dari masyarakat soal penyalahgunaan Dana Desa pada 2016. Penyimpangan-penyimpangan Dana Desa yang sering terjadi antara lain ada beberapa hal. Pertama adalah pengadaan barang dan jasa yang tidak sesuai. Kedua adalah markup anggaran yang biasanya tidak melibatkan masyarakat dalam musyawarah desa. Ketiga adalah penyelewengan Dana untuk kepentingan pribadi. Keempat lemahnya pengawasan dan kelima adalah penggelapan honor aparat desa. Dana Desa yang diselewengkan akan menghambat pertumbuhan ekonomi desa. Untuk mencegahnya agar tidak terjadi hal-hal yang tidak diinginkan soal penggunaan Dana Desa salah satu jalan adalah transparansi dan peran aktif warga untuk turut serta mengawasi penggunaan Dana Desa. Untuk mendukung kecepatan dan ketepatan penyaluran, penggunaan dan pengelolaan Dana Desa, Kemendes membentuk tim satgas Desa yang dipimpin Bibit Samad Rianto mantan pimpinan KPK. Selain berfungsi sebagai pengawas, Satgas Desa juga membantu evaluasi regulasi Dana Desa, sosialisasi, serta advokasi.

Dalam penelitian ini penyalahan pengelolaan dana desa belum terlihat, hanya saja minimnya sumber daya manusia yang mempu mengelola dana desa tersebut menadi kendala yang dihadapi oleh pemerintah desa.

Mencegah Penyalahgunaan Dana Desa melalui Transaksi Non Tunai

Beragam upaya dilakukan demi menyelamatkan program Dana Desa dari kejahatan korupsi. Salah satunya melalui kerja sama dengan Bank Indonesia (BI) melalui Gerakan Nasional Non Tunai (GNNT) untuk mencegah korupsi. BI melalui Kantor Perwakilan Cirebon telah mulai masuk desa dan menjalankan konsolidasi untuk mengembangkan gerakan ini. Pada penelitian ini untuk transaksi masih menggunakan dua alat yaitu tunai dan non tunai. Non tunai tidak selalu dapat digunakan mengingat akses untuk melakukan transaksi non tunai masih sangat terbatas, sementara beberapa pekerja memerlukan bayaran segera untuk memenuhi kebutuhan hidup mereka.

Keterbukaan Pengelolaan Dana Desa

Membangun dari desa adalah salah satu komitmen pemerintah untuk menghadirkan pemerataan ekonomi yang berkeadilan. Untuk itu, jumlah Dana Desa terus ditingkatkan setiap tahunnya. Masyarakat adat juga diberikan akses terhadap kesejahteraan. Untuk mewujudkan pemerataan ekonomi distribusi Dana 
Desa, penguatan kelembagaan desa, serta keterbukaan pengelolaan anggarannya perlu dikembangkan untuk disempurnakan. Pemerintah terus memastikan bahwa desa sebagai entitas terkecil mampu menjadi penopang utama pelayanan warga dan sekaligus penggerak perekonomian bangsa. Pengawasan Dana Desa terus diperluas oleh Kementerian Desa dengan menggandeng berbagai institusi mulai dari Polri, TNI, hingga para pemuka masyarakat dan pemuka agama diajak untuk mengawasai Dana Desa. Strategi dalam rangka keterbukaan ini diyakini cukup efektif menjadi alat pengontrol perilaku perangkat desa atau elite desa yang selama ini dianggap paling mengkinkan melakukan korupsi Dana Desa.

\section{Pengelolaan Dana Desa Secara Swakelola}

Mulai Januari 2018, Kemendesa PDTT memastikan Dana Desa harus dikelola dengan pola swakelola. Dana desa juga diprioritaskan pada kegiatan yang mampu menciptakan lapangan kerja seluas-luasnya bagi warga desa. Program Swakelola adalah kegiatan pengadaan barang/jasa di mana pekerjaannya direncanakan, dikerjakan, dan/atau diawasi sendiri oleh kementerian/lembaga/satuan kerja perangkat daerah/institusi lainnya sebagai penanggung jawab anggaran, instansi pemerintah lain dan/atau kelompok masyarakat. Sehingga dalam penelitian ini disampaikan bahwa dana desa untuk beberapa pembangunan di desa dilakukan oleh msayarakat dan melibatkan kaum mileneal desa dalam menjalankan pembangunan tersebut.

\section{Kerja Sama Pengawasan Dana Desa}

Dalam rangka memaksimalkan kerja sama pengawasan dana desa dan percepatan pembangunan di desa-desa, Kemendes PDT telah membuat dan menandatangani MoU dengan pihak kejaksaaan, yaitu MoU tentang pelaksanaan dan koordinasi dalam rangka memaksimalkan dan mengoptimalkan kerja sama antara kedua belah pihak dalam pengawasan dana desa agar ke depannya minim dari penyimpangan. Dengan adanya optimallisasi kerja sama antara Kemendes dan
Kejaksaan ini diharapkan proses pendistribusian dana desa berjalan dengan tertib dan terhindar dari pemanfaatan oknum kepala daerah untuk kepentingan pribadi dan kelompok. Pihak kejaksaan menyadari berjalannya program dana desa yang bersih dapat membantu program percepatan pemerintah pusat dalam pembangunan desa-desa pihak kejaksaan juga mengubah paradigma di bidang pengawasan dari mencari kesalahan beralih ke pengawasan dan dukungan kepada kepala desa dalam pengelolaan dana desa sehingga menjadi peluang bagi kejaksaan untuk menjadi mitra kepala desa dalam pembangunan desa yang menggunakan dana desa sehingga pembangunan dapat berjalan sesuai dengan target.

Dalam penelitian juga disampaikan oleh kepala desa bahwa pihaknya sangat terbantu dengan adanya pengawasan dan pengarahan dari pihak lain dalam menjalankan dan mengelola dana desa supaya dapat membangun perekonomian masyarakat desa tumbang empas.

Faktor Pendukung Dan Penghambat Pemanfaatan Dana Desa Dalam Meningkatkan Ekonomi Masyarakat Desa Tumbang Empas Kecematan Mihing Raya Kebupaten Gunung Mas.

I. Faktor Pendukung

a. Dukugan Kebijakan Pemerintah (Ekstrenal)

Dukungan kebijakan pemerintah merupakan faktor yang berasal dari luar desa atau dapat disebut ekternal kebijakan konsep yang menjadi pedoman dasar bagi pemerintah untuk melaksanakan program. Kebijakan berupa peraturan bupati dan pertunjukan teknis pelaksanaan pengelolaan keuangan desa yang menjadi faktor pendukung penggunaan Dana Desa.

b. Sosialisasi Untuk Masyarakat (Internal)

Merupakan kebijakan yang bersal dari dalam atau diseabut internal sosialisasi merupakan proses penyampaian pembelajaran kepada kelompok sasaran dari suatu kebijakan. Tujuan sosialisasi yaitu untuk membantu kelompok sasaran kebijakan lebih megerti kebijakan yang baru yang akan diterapkan kepada 
masyarakat yang sebelumnya belum diketahui oleh masyarakat. Sosialisasi membantu proses yang cukup panjang untuk menerapkan peraturan atau program serta kegitan yang baru, sosialisasi pengelolaan Dana Desa kepada perangkat pemerintah desa memberi kontribusi yang sangat baik terhadap pengelolaan Dana Desa. Dengan adalnya sosialisasi tersebut pemerintah desa tumbang empas dapat memanfaatkan dana desa tersebut secara baik dan tepat sasaran guna memberikan dampak untuk kehidupan masyarakat.

\section{c. Sarana Prasarana Desa}

Sarana dan prasarana merupakan kebijakan pemerintah atau kebinjakan ekternal. Adalah gejala suatu yang dapat dipakai sebagai alat mencapat tujuan atau sarana sedangkan prasarana adalah segala sesuatu yang merupakan penunjang utama terselengaranya suatu proses. Sarana dan prasarana yang ada di desa tumbang empas menjadi penunjang efisisensi dan efektifitas penguanaan Dana Desa dalam meningkatkan ekonomi masyarakat.

2. Faktor Penghambat

a. Sumber Daya Manusia/ Aparatur Desa (Internal)

Sumber daya manusia yang dimiliki desa tumbang empas belum memadai dalam mengelola Dana desa disebabkan karena adanya kasus BPD yang masuk penjara karena narkoba oleh hal itu mengakibatkan penggunaan Dana Desa kurang maksimal karena pengunaan Dana Desa tidak bisa tersalurkan untuk masrakat.

\section{b. Partisipasi Masyarakat Desa (Ekternal)}

Partisipasi masyrakat adalah keikutsertaan masyarakat secara efektif dalam kontribusi dengan suka rela membantu proses perencanaan, sampai evaluasi dari program tersebut. Sebelum adanya Dana Desa. Namun sekarang sesudah adanya Dana Desa masyarakat desa tumbang empas tidak hanya menjadi ikut merencanakan program namun mereka memiliki penghasilan yang cukup untuk memperbaiki ekonomi keluarganya sesudah adanya Dana Desa melalui program usaha desa.

\section{KESIMPULAN}

Berdasarkan hasil penelitian maka penulis dapat menarik kesimpulan bahwa, pemanfaatan dana desa yang dilakukan oleh pemerintah desa tumbang empas sudah berjalan dengan baik. Beberapa bukti nyata adalah pembangunan infrastruktur seperti jalan, jembatan, posyandu, dan gorong-gorong serta program-program yang dijalankan oleh Pemerintah Desa Tumbang Empas. Meskipun demikian terdapat beberapa kendala dalam pemanfaatan dana desa tersebut, yaitu kurangnya kualitas sumber daya manusia dalam mengelola anggaran yang besar serta adanya aparat desa yang terdapat menggunakan narkoba hingga mengurangi kepercayaan masyarakat terhadap aparat desa.

Adapun saran yang dapat penulis ajukan adalah perlunya sosialisai dari pemerintah pusat hingga ke pemerintah daerah kemudian disampaikan kepada pemerintah desa dalam tangka tata kelola anggaran dana desa. Selanjutnya diperlukan komunikasi antar desar dalam berbagai pengalaman dalam mengelola dana desa, dan sekaligus dapat dijadikan penelitian lanjutan oleh peneliti selanjutnya dalam mengetahui secara mendalam penyaluran dan penggunaan dana desa ini.

\section{UCAPAN TERIMA KASIH}

Terima kasih kami ucapkan kepada Rektor Universitas Palangka Raya.

Terima kasih kami ucapkan kepada Dekan Fakultas Keguruan dan Ilmu Pendidikan

Terima kasih kami ucapkan kepada Ketua Program Studi Pendidikan Ekonomi

Terima kasih kami ucapkan kepada Kepala Desa Tumbang Empas beserta jajarannya.

Terima kasih kami ucapkan kepada seluruh masyarakat Desa Tumbang Empas, dan semua pihak yang terlibat sehingga penelitian ini dapat dilaksanakan dengan baik. 


\section{REFERENSI}

Afifuddin. 2009. Metodologi Penelitian Kualitatif. Bandung: CV Pustaka Setia

Aprilia, Theresia. 2014. Pembangunan Berbasis Masyarakat. Bandung: Alfabeta.

Ayustia, R. 2019. Mitra / Konsultan Pendamping Dana Desa Di Daerah Perbatasan. Jurnal Anterior , $19 \quad$ (I), I37-140. https://doi.org/I0.33084/anterior.v I9il.I I 36

Anwar, Abbas. 2012. Sistem Ekonomi Islam: Suatu Pendekatan Filsafat, Nilai-nilai Dasar, dan Instrumen. Jurnal Ilmiah Ekonomi Islam Allqtishad. Vol IV No. I.

A, Saibani. 2015. Pedoman Umum Penyelengaraan Pemerintahan Desa, Jakarta: Bee Media Pustaka.

Ambar, Teguh Sulistiani. 2004. Kemitraan dan Modelmodel Pemberdayaan. Yogyakarta: Gava Media.

Chabib Sholeh, Heru Rochansjah. 2015. Pengelolaan Keuangan Desa. Bandung: Fokus Media.

Edi Suharto. 2015. Membangun Masyarakat Memberdayakan Rakyat. Bandung: Refika Aditama.

Sugiyono. 2007. Metode Penelitian Pendidikan Pendekatan Kuantitatif dan Kualitatif, dan R\&D. Bandung. Alfabeta.

Sugiyono. 2010. Metode Penelitian Bisnis (Pendekatan Kuantitatif dan R\&D). Bandung: Alfabeta.

Sutopo. H. B. 2002. Metode Penelitian Kualitatif Dasar Teori dan Terapannya Dalam Penelitian. Surakarta: Sebelas Maret University Press.

Soekarto, Soerjono. 2002. Teori Peranan. Jakarta: Bumi Askara.

Soekanto, Soerjono. 1990. Peraturan Perundanganundangan Republik Indonesia Nomor 17 Tahun 2003 Tentang Anggaran Pendapatan dan Belanja Negara Tahun Anggaran 2014 Sosiologi Suatu Ilmu Pengantar. Jakarta Rajawali Press.

Republik Indonesia. Undang-undang Nomor 6 Tahun 2014 Tentang Desa.
Peraturan Pemerintah Nomor 43 Tahun 2014 Tentang Pelaksanaan Undang-undang Nomor 6 Tahun 2004.

Peraturan Pemerintah Nomor 60 Tahun 2014 Tentang Dana Desa Bersumber dari APBN.

Permendagri Nomor II4 Tahun 2014 Tentang Pedoman Pembangunan Desa.

Putro, HS, \& Kartini, NH. 2020. Implementasi Penggunaan Dana Desa Tahun Anggaran 2019 Berdasarkan Permendes Nomor 16 Tahun 2018 Tentang Prioritas Penggunaan Dana Desa Tahun 2019 Di Desa Kanamit Barat Kecamatan Maliku Kabupaten Pulang Pisau. Jurnal Anterior , 19 (2), 55-65. https://doi.org//0.33084/anterior.v19i2.1507

Widoyoko, Eko Putro. 20l4. Teknik Penyusunan Instrumen Penelitian. Yogyakarta : Pustaka Pelajar 